Anna Babicka-Wirkus

Akademia Pomorska w Słupsku

E-MAIL: anna.babicka-wirkus@apsl.edu.pl

\title{
Recenzja książki Rzeczy - Kultura - Edukacja pod redakcją Maksymiliana Chutorańskiego i Anety Makowskiej
}

\section{STRESZCZENIE}

Celem tekstu jest prezentacja głównych tez i wniosków autorek i autorów, których artykuły składają się na recenzowany tom. Istotnym aspektem jest również wskazanie ważnych wątków i obszarów dla współczesnej myśli pedagogicznej.

SŁOWA KLUCzOWE: pedagogika rzeczy, posthumanizm, zwrot ku materialności

Książka pod redakcją Maksymiliana Chutorańskiego oraz Anety Makowskiej jest zbiorem artykułów poświęconych szeroko zakrojonej problematyce pedagogiki rzeczy. Jak podkreślają redaktorzy, jest ona efektem pracy Grupy Badaczy Pedagogiki Rzeczy oraz zaproszonych autorów, którzy zechcieli pochylić się nad zagadnieniem materialności w kontekście edukacji. Warto zaznaczyć, że książka nie jest zlepkiem niepowiązanych artykułów, lecz starannie przygotowanym tomem, w którym każdy kolejny rozdział stanowi istotny element całości. Całość ta jest doskonałym punktem wyjścia dla wielu inspiracji teoretycznych i badawczych w zakresie rozwijania nowego nurtu poznawczego w pedagogice, jakim jest pedagogika rzeczy. Jest ona także odpowiedzią badaczy rzeczywistości edukacyjnej na dokonujące się w świecie zmiany i na trendy badawcze szeroko rozwijane w naukach społecznych i nie tylko.

Analizowana książka podejmuje problematykę zwrotu ku materialności w myśleniu o świecie oraz o człowieku i jego relacjach z materialnymi formami, które od zawsze stanowiły istotny, nieodłączny, lecz często marginalizowany aspekt ludzkiego istnienia. Jednak to dopiero obecnie obcowanie istot ludzkich z rzeczami, zwierzętami, przyrodą weszło w inny wymiar, który nadaje ludziom i nie-ludziom status równorzędny. Uprzywilejowana pozycja podmiotu ludzkiego została zakwestionowana. Już nie tylko człowiek wra- 
stając w kulturę uczy się posługiwania przedmiotami i ich wytwarzania, lecz owe nie-ludzkie byty podporządkowują sobie jednostkę ludzką, zawłaszczając jej dotychczas uprzywilejowany status i wyznaczając zakres jej działań. Sytuacja ta uwidacznia się chociażby na przykładzie relacji z telefonem komórkowym, który stanowi obecnie nie tylko użyteczny przedmiot, lecz jest elementem definiującym swojego posiadacza i wyznaczającym przebieg, charakter, jakość oraz częstotliwość jego interakcji z innymi ludźmi i rzeczami. Nie-ludzkie byty osiągnęły we współczesnej kulturze status równorzędny ludzkiemu, z tego też powodu refleksja i badania pedagogiczne również powinny zmierzać w kierunku rozpoznania zacierania się dystynkcji na ludzkie - nie-ludzkie, naturę - kulturę, podmiot - przedmiot. W centrum badań zaś powinny znaleźć się „hybrydy naturokultury” (s. 11), które podlegają nieustannym rekonfiguracjom. Specyfika i zmienność tych relacji zakreśla pole analityczne podejmowanych w omawianej książce zagadnień.

Redaktorzy recenzowanej pozycji pragną poprzez zgromadzone teksty nakreślić ramy „pedagogiki rzeczy” bądź „nie(tylko)ludzkiej pedagogiki”, która koncentrowałaby się na analizie „zarówno znaczeń nadawanych rzeczom w procesach edukacyjnych, jak i opisowi związków ludzi oraz rzeczy, a także rekonstrukcji dynamicznych relacji między ludzkimi a pozaludzkimi aktorami procesów edukacyjnych i kulturowych; edukacyjnych relacji między tym, co ludzkie i pozaludzkie" (s. 12). Jest to ważne i ambitne przedsięwzięcie, które ma szczególne znaczenie dla współczesnej refleksji pedagogicznej.

$\mathrm{W}$ artykule wprowadzającym w problematykę książki redaktorzy szkicują trzy sposoby rozumienia pedagogiki rzeczy (s. 13). Pierwszy odnosi się do refleksji nad znaczeniami tworzonymi w interakcjach społecznych. Drugi sposób natomiast związany jest $\mathrm{z}$ aspektem badawczym, który sprowadza się do uchwycenia specyfiki działania przedmiotów w procesach edukacyjnych. Trzeci zaś sposób definiowania tego nurtu myślenia pedagogicznego odnosi się do posthumanistycznego namysłu nad edukacyjnymi relacjami zachodzącymi w nie(tylko)ludzkich zbiorowościach. Odzwierciedlenie tych trzech ujęć można odnaleźć w omawianej książce, która składa się z trzech części ukonstytuowanych na podstawie dwunastu rozdziałów.

W części otwierającej, zatytułowanej Widzieć rzeczy (i ludzi), autorzy skupiają się na objaśnieniu specyfiki zwrotu ku materialności w myśleniu pedagogicznym i społecznym. Tekst Maksymiliana Chutorańskiego Posthumanizm(y) i pedagogika zawiera w sobie wiele nawiązań do różnych koncepcji w obrębie szeroko pojętego paradygmatu posthumanistycznego. Autor, szkicując złożoność tego podejścia, wskazuje jednocześnie na wielość pytań, problemów, które wiążą się z przyjęciem takiej perspektywy teoretycznej w myśleniu 
pedagogicznym. Konkludując swoje analizy, Chutorański postuluje o niedeprecjonowanie pozycji człowieka wobec rzeczy, lecz o uwzględnienie specyfiki usytuowania bytów ludzkich i nie-ludzkich w świecie. Chodzi o badanie i analizę procesów edukacyjnych przez pryzmat podejścia, które nie wyróżnia człowieka ze względu na jego wyjątkowość, ale o spojrzenie na te procesy z perspektywy symboliczno-materialnych relacji zachodzących między ludzkimi i nie-ludzkimi aktorami. Praktyki pedagogiczne nie powinny być zatem zarezerwowane wyłącznie dla ludzi, lecz powinniśmy na nie patrzeć jak na proces nieustannego stawania się, rekonfiguracji między elementami edukacyjnych kolektywów, tworzonych przez ludzi, zwierzęta, przyrodę, rzeczy.

Krzysztof Abriszewski w artykule Przedmioty ideologii podejmuje problematykę rzeczy w kontekście podejścia performatywnego do ideologii, zaproponowanego przez Slavoja Žižka. Jest to ujęcie odmienne od teorii ANT, gdzie rzecz jest redukowalna do narzędzia, czy też koncepcji Rolanda Barthesa, zgodnie z którą to, co materialne jest nośnikiem niematerialnych znaczeń. Propozycja słoweńskiego filozofa stanowi inspirujące podejście, ponieważ bierze pod uwagę zarówno znaczenie materialne bytów pozaludzkich, jak i ich znaczenie symboliczne, głęboko zakorzenione w kulturze. Według Abriszewskiego zastosowanie teorii Žižka może być przydatne do badania relacji rzeczy-człowiek-kultura, ponieważ pozwala uchwycić pozaludzkie byty w kontekście ich specyfiki materialnej i niematerialnej. Rzeczy w podejściu Žižka są nie tylko obiektami, są nie tylko mniej lub bardziej ważnym elementem praktyk kulturowych, ale one również zapośredniczają porządek społeczny oraz współkonstruują porządek i pragnienia (s. 54). Analiza zatem skierowana jest na pewną performatywność aktorów pozaludzkich w kontekście ich relacji z aktorami ludzkimi. Wykracza się tu zatem poza analizy odnoszące się do specyfikacji i użyteczności rzeczy jako narzędzi oraz poza analizy semiotyczne.

Kolejny tekst, autorstwa Marii Czerepaniak-Walczak, wprowadza do rozważań na temat relacji aktorów ludzkich z nie-ludzkimi pojęcie solostalgii, które autorka ujmuje jako tęsknotę, ból wywołany poczuciem braku komfortu. Z takim uczuciem możemy się spotkać, gdy rzecz, która na dobre zagościła w naszym życiu, na przykład telewizor, nie spełnia już najnowszych wymagań technologicznych i tym samym ogranicza nas w aspekcie luksusu najbardziej zaawansowanej technologicznie możliwości jej użytkowania. Autorka analizuje poziomy świadomości wyróżnione przez Paula Freire w kontekście odczuwania solostalgii i wskazuje, że tylko świadomość krytyczna może być skuteczną ochroną przed cierpieniem wynikającym $\mathrm{z}$ braku poczucia komfortu. Świadomość krytyczna oparta jest na poczu- 
ciu sprawstwa igotowości do podejmowania decyzji. Zasadza się na wiedzy na temat usytuowania człowieka w świecie i jego relacjach z elementami nie-ludzkimi. Czerepaniak-Walczak w konkluzjach podkreśla, że „Rzeczy wyzwalają i rzeczy zniewalają” (s. 64), przez co niosą ze sobą potencjał do osiągania nowych pól wolności bądź też ujarzmienia.

W rozdziale dotyczącym pedagogiki Marii Montessori, Jarosław Jendza analizuje uwikłanie tego podejścia wychowawczego $\mathrm{w}$ relacje $\mathrm{z}$ przedmiotami. Wskazuje na znaczenie strukturalno-dynamicznego przygotowania otoczenia oraz rzeczy się w nim znajdujących dla rozwoju dzieci. Porządek rzeczy w tym otoczeniu powinien odzwierciedlać porządek świata. $\mathrm{W}$ tym wymiarze podkreślone zostaje znaczenie rzeczy i relacje, jakie za ich pośrednictwem są tworzone (z ludźmi i innymi nie-ludzkimi bytami). Stanowią one nieodłączny aspekt rzeczywistości edukacyjnej, który nie może być pomijany we współczesnych analizach pedagogicznych.

Kolejna część recenzowanej książki dotyczy dwoistej relacji zachodzącej między ludźmi i rzeczami. Rozpoczyna ją tekst Marka Krajewskiego, w którym autor dokonuje interesującej analizy wielopoziomowego funkcjonowania dzwonka szkolnego i nie tylko szkolnego. Dzwonek z jednej strony ma swoją materialność, która w przestrzeni środowiska szkoły jest zazwyczaj maskowana, z drugiej zaś ma również wymiar immaterialny, sprowadzający się do urządzania porządku dnia szkolnego. „Dzwonek szkolny nie tylko (...) strukturyzuje życie szkoły, ale codziennie artykułuje również jej zasadę organizacyjną: jest ona instytucją hierarchiczną, w której istnieje jakieś centrum dowodzenia delegujące część swoich nadzorczych obowiązków na innych, zarówno na ludzi, jak i na przedmioty oraz urządzenia" (s. 87). Dzwonek także może być używany w aspekcie subwersyjnym, gdy następuje jego wyłączenie lub wyciszenie. Podjęcie tego typu działań przez niektóre ze szkół jest wyrazem ich niezgody na tradycyjnie pojmowany system edukacji instytucjonalnej.

Andrzej Nowak w artykule Ja i mój cyfrowy Doppelgänger. Self-tracking jako dwuznaczne urzeczowione samowychowanie, analizuje relacje człowieka z urządzeniami, rzeczami pozwalającymi mu na kontrolowanie i poznawanie siebie. W tym aspekcie rzeczy są niezbędnym elementem samopoznania i samokontroli człowieka. Relacja ta posiada jednak także inny wymiar, a mianowicie mniej lub bardziej dobrowolnego godzenia się jednostki ludzkiej na poddanie się kontroli przez rzecz, algorytm, firmę zbierającą dane na temat aktywności ludzkich. Jak wskazuje autor: „Biometria, urządzenia monitorujące stają się nową wersja praktyk dyscyplinujących" (s. 97), które posługują się miękkimi metodami zniewalania. Używanie zegarków sportowych, pul- 
sometrów, aplikacji monitorujących nasze tętno, ilość spalanych kalorii, długość snu itp. pozwalają nam kontrolować i regulować nasze organizmy, dzięki czemu możemy pracować nad ulepszaniem samych siebie. Z drugiej strony, są narzędziem biopolitycznej władzy, która w niedostrzegalny sposób determinuje sposoby naszego działania.

Aneta Makowska w swoim tekście podjęła problem zaangażowania rzeczy w proces wychowania. Przeanalizowała znaczenie pakietów macierzyńskich na przykładzie pudełka, jakie otrzymują rodzice po urodzeniu się dziecka. W pudełku tym znajduje się cała wyprawka, która służyć ma dziecku i matce w pierwszych miesiącach po porodzie. Skład tych pudełek oraz materiały, z jakich są tworzone, zależne są od możliwości danego państwa oraz potrzeb matki i dziecka, wynikających z usytuowania kulturowego, geograficznego, społecznego i ekonomicznego kraju. A zatem skład pakietu macierzyńskiego jest inny na przykład w Finlandii i w Wenezueli. Jego zawartość zaś odzwierciedla politykę państwa wobec nowo narodzonych dzieci i ich rodziców/opiekunów. Jest zatem przykładem, jak za pośrednictwem rzeczy tworzone są specyficzne relacje edukacyjne między ludzkimi i nie-ludzkimi aktorami.

W kolejnym rozdziale Lucyna Kopciewicz i Hussein Bougsiaa podejmują problematykę wspólnego tworzenia przestrzeni edukacyjnej przez podmioty ludzkie i nie-ludzkie. Autorzy zwracają uwagę na fakt, że obecnie nie należy postrzegać technologii wyłącznie jako elementu życia człowieka, lecz należy spoglądać na łączące ich relacje przez pryzmat ludzko-technologicznego kolektywu, który jest nierozłączny i tworzy pewną całość. Posługiwanie się technologią cyfrową jest ważnym składnikiem procesu edukacyjnego, jednak założenia i cele, jakie stawiają sobie edukatorzy, mają znaczenie dla kierunku, w jakim zmierzać będzie ten proces. $W$ artykule tym autorzy wskazują na znaczenie człowieka dla interpretacji relacji z rzeczami, ponieważ to oni określają cele i zakresy posługiwania się technologią. Człowiek znajduje się zatem na początku i końcu interakcji z technologią, próbując wykorzystać ją do realizacji swoich zamierzeń. Nie oznacza to jednak, że ona biernie mu się poddaje. W pewnym (znacznym) zakresie technologia również determinuje życie podmiotów ludzkich.

Markus Lipowicz z kolei spogląda na proces ulepszania człowieka przez pryzmat działań eugenicznych i transhumanistycznych, który kontrastuje z kulturowo zakorzenionym procesem wychowania. Kluczowe pytanie, jakie stawia autor, dotyczy problematyki „ulepszania” człowieka i tego, na ile przyzwalamy społecznie na wykorzystywanie narzędzi, środków, rzeczy, technologii do stworzenia człowieka odpowiadającego określonemu modelowi 
wychowawczemu, a na ile odrzucamy ingerencje w materiał genetyczny, które również mają na celu produkcję pewnego ludzkiego ideału. Zarówno wychowanie, jak i eugenika liberalna oraz transhumanizm zmierzają do stworzenia pożądanego człowieka. Dwa ostatnie sposoby są próbą zastąpienia tradycyjnego narzędzia, jakim jest proces wychowania i kształcenia, bardziej nowoczesnym, który sprowadza się do genetycznego ulepszania i biotechnologicznych interwencji. Poza dużymi możliwościami sposoby te niosą ze sobą również szereg zagrożeń wynikających z próby stworzenia idealnego człowieka. W tym kontekście pojawia się też kwestia prawa jednostki ludzkiej do swojego ciała i decydowania o nim. Kwestie te z perspektywy pedagogicznego namysłu są kluczowe dla definiowania istoty człowieka, wychowanka, ucznia.

Ostatnia część omawianej książki dotyczy zagadnienia materialności miejsca. Otwiera ją tekst Marii Mendel, która, odnosząc się do przykładów konkretnych miejsc w Gdańsku, ukazuje edukacyjny i wychowawczy wymiar ich materialności. Procesy wychowawcze i socjalizacyjne zawsze odbywają się „gdzieś”, w pewnym miejscu, które poprzez swoje widma (w ujęciu Derridiańskim) oddziałuje na owe procesy i je dopełnia. Miejsce pedagogiczne, jak stwierdza autorka "[s]tanowi środowisko autokreacji i uczy, czyniąc to z ukrycia, skrywając tak siebie, jak «inne rzeczy» - widma" (s. 158). Nierzadko jest swoistym baśniokręgiem, który wyrasta z mitów, opowieści i legend na jego temat. Baśniokręgi są również widmami nawiedzającymi dane miejsce i mającymi znaczenie dla ludzi, którzy w ich obrębie żyją. A zatem refleksja pedagogiczna powinna uwzględniać widmowość miejsc pedagogicznych, ponieważ mają one znaczenie dla jakości przebiegających w nich procesów.

Nieco inne miejsca pedagogiczne omawia w swoim tekście Kamila Kamińska-Sztark, która skupia się na muzeach społecznych. Spontanicznie powstające przestrzenie muzealne mają szczególne znaczenie mimetyczne, ponieważ pozwalają na odtworzenie i naśladowanie kosmogonii minionego świata. Umożliwiają one zagłębienie się w rzeczywistość, która już minęła. Jej widma jednak nawiedzają współczesne przestrzenie, naznaczając je w swoisty sposób. Za pośrednictwem izb pamięci, skansenów, muzeów społecznych, widma te są lepiej dostrzegalne i bardziej zrozumiałe dla współczesnych.

Artykułem zamykającym tę część i jednocześnie książkę jest tekst Oskara Szwabowskiego. Autor, omawiając problematykę ruchów społecznych, analizuje znaczenie pozaludzkich czynników kształtujących ową rzeczywistość. Nie tylko człowiek i jego poglądy oraz odwaga w walce o nie, ale także układ ulic, drogi ucieczki, materiały, z jakich wykonane są transparenty, ubranie, środki komunikacji miejskiej tworzą niezbywalne i nieredukowalne elementy protestów. Pojawienie się ruchów społecznych w postaci marszów, manife- 
stacji, strajków, zmienia zastaną przestrzeń ulicy, zawłaszcza ją. Ten proces dokonuje się również w kierunku odwrotnym - przestrzeń ulicy także zmienia pojawiające się w jej obrębie ciała, zmusza je do działania, a nie do dyskutowania. Ulica uwalnia ciała z ujarzmiającego uścisku maszyny dydaktycznej, ale jednocześnie wystawia je na zagrożenie, na potencjalne zranienie, przez co obnaża ich słabości. Znalezienie się w stanie niebezpieczeństwa pobudza jednak ciała do działania i przekształcania rzeczywistości.

Reasumując, recenzowana książka jest pozycją istotną dla dorobku współczesnej myśli pedagogicznej. Jest ona inspirująca nie tylko pod względem poznawczym, ale też badawczym. Jej głównym walorem jest zaszczepienie w czytelniku ciekawości i niedosytu prowadzącego do dalszych lektur i poszukiwania odpowiedzi na pytania pojawiające się w książce, które dotyczą statusu i usytuowania rzeczy, pozaludzkich aktorów, przyrody, technologii oraz relacji, w jakie wchodzą/tworzą one z bytami ludzkimi. Uwalnia ona również pedagogów z kajdan myślenia antropocentrycznego, co umożliwia stawianie nowych pytań na temat rzeczywistości edukacyjnej.

\section{BIBLIOGRAFIA}

Chutorański, M., Makowska, A. (red.) (2019). Rzeczy - Kultura - Edukacja. Szczecin: Wydawnictwo Naukowe Uniwersytetu Szczecińskiego.

\section{SUMMARY}

Review of the Book: Things - Culture - Education, ed. by Maksymilian Chutorański \& Aneta Makowska

The purpose of the text is to present the main theses and conclusions by the authors whose articles make up the reviewed volume. An important aspect is also the identification of threads and areas important for the contemporary pedagogical thought. KEYWORDS: pedagogy of things, posthumanism, a turn towards materiality 